\title{
Subtle effect of Xenos vesparum (Xenidae, Strepsiptera) on the reproductive apparatus of its male host: Parasite or parasitoid?
}

\author{
L. Beani ${ }^{a, *}$, D. Marchini ${ }^{\text {b }}$, F. Cappa ${ }^{\mathrm{a}}$, I. Petrocelli ${ }^{\mathrm{a}}$, M. Gottardo ${ }^{\mathrm{b}}$, F. Manfredini ${ }^{\mathrm{c}}$, F. Giusti $^{\mathrm{b}}$, \\ R. Dallai ${ }^{\mathrm{b}}$ \\ a Dipartimento di Biologia, Università di Firenze, Via Madonna del piano 6, 50019 Sesto Fiorentino (Firenze), Italy \\ b Dipartimento di Scienze della vita, Università di Siena, Via Aldo Moro, 53100 Siena, Italy \\ ' School of Biological Sciences, Royal Holloway University of London, Egham TW20 OEX, United Kingdom
}

\section{A R T I C L E I N F O}

\section{Keywords:}

Polistes dominula

Parasitic castration

Functional morphology

Male reproductive apparatus

Age effect

Accessory gland secretion

\begin{abstract}
A B S T R A C T
Parasitic castration is an adaptive strategy where parasites usurp the hosts' reproductive physiology to complete their life cycle. The alterations in the host traits vary in their magnitude, from subtle changes in the host morphophysiology and behaviour to the production of complex aberrant phenotypes, which often depend on the host gender. The strepsipteran macroparasite Xenos vesparum induces dramatic behavioural and physiological changes in its female host, the paper wasp Polistes dominula, while its effect on the male phenotype is largely unknown.

In this study we investigated how a single $X$. vesparum parasite influences the functional morphology of $P$. dominula male reproductive apparatus. We performed morphometry and ultrastructure characterization of corpora allata, testes, seminal vesicles and accessory glands in parasitized and unparasitized males, and also in young and old males to control for the effect of age on the natural deterioration of these organs. Our results show that age significantly affects the development of male reproductive apparatus. A low parasite load - one parasite per host is the common prevalence in the field - has only a marginal impact on the reproductive morphology of $P$. dominula males, affecting quantitatively but not qualitatively the protein content of male accessory glands. Thus, in male $P$. dominula wasps, $X$. vesparum appears to behave as a true "parasite", in clear opposition to the role of "parasitoid" that it takes in female hosts where castration causes the reproductive death.
\end{abstract}

\section{Introduction}

Parasitic castration represents an extreme example of phenotype manipulation. Parasitic castrators (or sterilizers) are organisms that manage to exploit the reproductive pathways of the host for their own development and reproductive output: they do so by diverting energy from gonad development or by secreting castrating hormones (Kuris, 1974; Baudoin, 1975; Hechinger et al., 2009; Lefèvre et al., 2009a). Parasitic castrators can also influence host morphology, behaviour and the evolution of host life history traits (Lafferty, 1993a; Hiroki et al., 2004; Hughes et al., 2004; Beani et al., 2011). For example, they can selectively target a specific developmental stage or host gender, hence exposing the host population to different selective pressures (Minchella, 1985; Lafferty, 1993b; Ebert et al., 2004; Beani et al., 2011; Cappa et al., 2014).

Strepsiptera parasitize seven different orders of Insecta (Kathirithamby, 2009; Cook, 2014) and may be defined parasitoids as they cause the "reproductive death" of the host (sensu Kuris, 1974). On the other hand, the boundary between parasitoid and parasite is plastic for this enigmatic order of insects. Similarly to other parasitoids, they kill the host only after completion of their life cycle but, in line with typical parasites, they do not reduce host viability, mobility and lifespan. Host longevity is another important feature to consider when analysing parasitic castrators, as their fitness depends on a trade-off between consuming the host for their own development and maintaining the host alive until they are able to reproduce (Lefèvre et al., 2009 b). In the literature of castrators (also called "body snatchers", Lafferty and Kuris, 2009) "the term castration is used loosely" because the putatively "castrated" hosts are often capable to produce few gametes (Poulin, 2011). Among them, Xenos vesparum (Xenidae, Strepsiptera) is of particular interest. $X$. vesparum is closely associated with the social wasp Polistes dominula (Hughes et al., 2004; Beani, 2006), and while having a dramatic impact on the phenotype of the female hosts (Beani et al., 2011), including castration (Strambi et al., 1982;

\footnotetext{
* Corresponding author.

E-mail address: laura.beani@unifi.it (L. Beani).
} 
Kathirithamby, 2009; Beani et al., 2011), it has a less understood effect on the male host phenotype, in terms of sexual behaviour and morphology of the reproductive apparatus (Cappa et al., 2014).

Research on Polistes wasps, from the first physio-ethological study by Leo Pardi (1948) to more recent molecular phylogeny and sociogenomics (Schmitz and Moritz, 1998; Carpenter, 2003; Sumner et al., 2006; Toth et al., 2007, 2010, 2014; Berens et al., 2015, 2016; Geffre et al., 2017), has been mainly focused on the socially competitive and cooperative females, while the male phenotype has not received equal attention (Beani et al., 2014; Heinze, 2016). The "so transparently Darwinian" scenario (West-Eberhard, 2006) regulating social life among females has centered the interest on the colony. Several reasons may underlie the paucity of attention on Polistes male phenotype, starting with the lack of conspicuous armaments and ornaments (Baer, 2014; but see Izzo and Tibbetts, 2012; De Souza et al., 2014; Cappa et al., 2016), which makes Polistes males less attractive to the human eye than males of other species. Their lifespan is short (1-2 months) and for the most part spent outside the nest (West-Eberhard, 1969), where mating generally occurs on leks at landmarks (Thornhill and Alcock, 1983; Beani, 1996; Alcock and Thornhill, 2014). Interestingly, comparative studies across eusocial insects (ants, bees, wasps and termites) have revealed that long-term sexual selection on male traits (including genitalia, sperm and accessory glands) has strongly influenced the evolution of key aspects of social life such as colony success and paternity (Boomsma et al., 2005, 2009; Beani et al., 2014; Heinze, 2016).

From the point of view of the immune system, males of social insects seem to represent the weakest part of the colony (see Cappa et al., 2015). It has been hypothesized that because of their haploid condition, males should be more susceptible to parasites and pathogens than diploid females, as they possess a smaller repertoire of genetic combinations that enable them to effectively fight infections (O'Donnell and Beshers, 2004; Baer and Schmid Hempel, 2006; Retschnig et al., 2014). The "haploid susceptibility hypothesis", however, does not apply to every system and several studies suggest that not only genetic condition, but also male life history traits can affect male resistance to parasites and pathogens (Ruiz-Gonzàlez and Brown, 2006; Cappa et al., 2015).

In the present study, we investigate the impact of one $X$. vesparum on Polistes male reproductive morpho-physiology. First, we compare the size of corpora allata, testes, seminal vesicles and accessory glands in $P$. dominula males of different ages, either parasitized by one male $X$. vesparum or unparasitized. Furthermore, we integrate these observations with the ultrastructure characterization of the reproductive apparatus and the protein profile of the accessory glands' secretion in immature and mature males, either parasitized by one parasite or unparasitized. Our approach represents a novelty with respect to previous studies, where the reproductive apparatus of Polistes males has been investigated in unparasitized mature individuals and adopting a phylogenetic perspective (Dirks and Sternburg, 1972; Jamieson et al., 1999; Salerno and Turillazzi, 2001; Araùjo et al., 2010). Previous findings on the effect of Xenos parasites on the host reproductive physiology highlight a substantial gender-related divergence. The ovaries of infected $P$. dominula females are always undeveloped and thread-like, regardless of X. vesparum load and gender (Beani et al., 2011). Preliminary analyses showed that in males, unlike in females, one parasite does not affect the general morphology of the reproductive apparatus (Cappa et al., 2014). It is therefore evident that male and female phenotypes respond differently to this parasite. However, our previous work was not able to reveal whether there is an effect of the parasite on the male apparatus at a deeper level (morphometry, ultrastructure and protein secretion of accessory glands). The in-depth morpho-functional approach that we propose in this study helps to clarify whether $X$. vesparum should be defined as parasite or parasitoid (for a review on the definition "parasite or parasitoid" in Strepsiptera, see Kathirithamby, 2009). Such a task requires that one takes into account the host gender
Table 1

Means and SDs for CA volume, SV and AG area in four groups of males: parasitized and unparasitized (immature vs mature)

\begin{tabular}{|c|c|c|c|}
\hline & $\begin{array}{l}\text { Corpora allata volume } \\
\left(\mathrm{mm}^{3}\right)\end{array}$ & $\begin{array}{l}\text { Seminal vesicle } \\
\text { area }\left(\mathrm{mm}^{2}\right)\end{array}$ & $\begin{array}{l}\text { Accessory } \\
\text { glands area } \\
\left(\mathrm{mm}^{2}\right)\end{array}$ \\
\hline \multirow{3}{*}{$\begin{array}{c}\text { Unparasitized } \\
\text { immature } \\
\text { males }\end{array}$} & Mean $=1.67 \times 10^{-3}$ & Mean $=0.064$ & Mean $=0.153$ \\
\hline & $\mathrm{SD}=5.64 \times 10^{-4}$ & $\mathrm{SD}=0.013$ & $\mathrm{SD}=0.029$ \\
\hline & $\mathrm{N}=9$ & $\mathrm{~N}=12$ & $\mathrm{~N}=12$ \\
\hline \multirow{3}{*}{$\begin{array}{l}\text { Parasitized } \\
\quad \text { immature } \\
\text { males }\end{array}$} & Mean $=1.67 \times 10^{-3}$ & Mean $=0.076$ & Mean $=0.169$ \\
\hline & $\mathrm{SD}=1.14 \times 10^{-4}$ & $\mathrm{SD}=0.011$ & $\mathrm{SD}=0.024$ \\
\hline & $\mathrm{N}=2$ & $\mathrm{~N}=7$ & $\mathrm{~N}=7$ \\
\hline \multirow{3}{*}{$\begin{array}{l}\text { Unparasitized } \\
\text { mature } \\
\text { males }\end{array}$} & Mean $=1.19 \times 10^{-3}$ & Mean $=0.085$ & Mean $=0.189$ \\
\hline & $\mathrm{SD}=3.91 \times 10^{-4}$ & $\mathrm{SD}=0.026$ & $\mathrm{SD}=0.058$ \\
\hline & $\mathrm{N}=13$ & $\mathrm{~N}=21$ & $\mathrm{~N}=21$ \\
\hline \multirow{3}{*}{$\begin{array}{c}\text { Parasitized } \\
\text { mature } \\
\text { males }\end{array}$} & Mean $=1.18 \times 10^{-3}$ & Mean $=0.080$ & Mean $=0.182$ \\
\hline & $\mathrm{SD}=3.40 \times 10^{-4}$ & $\mathrm{SD}=0.021$ & $\mathrm{SD}=0.031$ \\
\hline & $\mathrm{N}=10$ & $\mathrm{~N}=19$ & $\mathrm{~N}=19$ \\
\hline
\end{tabular}

and its castration, i.e. its reproductive death, even in a scenario when the parasite load is the lowest (i.e. one parasite), which is indeed the most common scenario in natural populations (Hughes et al., 2003, 2004).

\section{Materials and methods}

\subsection{Sample collection}

P. dominula mature males were collected from different natural lek systems located in the surroundings of Florence, in August 2011-13, i.e. at the peak of male activity (Beani, 1996). These males performing territorial behaviour were at least 15-20 days old as inferred from the yellow colour of their eyes, a reliable age indicator (Strassmann, 1981). Males parasitized by $X$. vesparum represent a variable segment of the male population, depending on the global parasite prevalence in the area (up to $30 \%$ on leks near Florence, Cappa et al., 2014).

To control for any possible effect of the age of the wasp on its reproductive apparatus, a sample of sexually immature black-eyed males was collected from 5 nests, naturally parasitized in the field and housed in laboratory. These males, either parasitized by one Xenos or unparasitized, were analysed 8-10 days after their emergence, when they were inactive on the nest. The necessity to use laboratory-emerged males from field-infected nests derives from the "cryptic nature" of $X$. vesparum (Beani, 2006). The early desertion of the colony by infected wasps, often before the extrusion of the parasite (around 5 days, Hughes et al., 2004), makes it extremely difficult to collect immature parasitized males on field nests. Although lab rearing may affect wasp physiology in a different way than natural conditions in the field (Jandt et al., 2015), the inactivity of males on the nest during the first two weeks from their emergence (Beani, 1996) makes the two groups of wasps directly comparable.

For this study, we selected males parasitized by one $X$. vesparum of the same developmental stage, identified as a single male cephalotheca or female cephalothorax extruded through the host cuticle (Kathirithamby, 2009). At this stage, the sexual dimorphism is relatively limited in terms of size and shape (Beani, 2006) and multiple cuticle layers cover both males and females Xenos, thus preventing any exchange with the host in either sexes of the parasite. Moreover, the sex of the parasite did not affect male wasp sexual behaviour in a previous study that we carried on (Cappa et al., 2014). For these reasons, and because of the small size of our sample, we did not consider the sex of the parasite as a factor in our analyses. From now on, we label as "parasitized" any male wasp infected by one extruded Xenos parasite, male or female. 


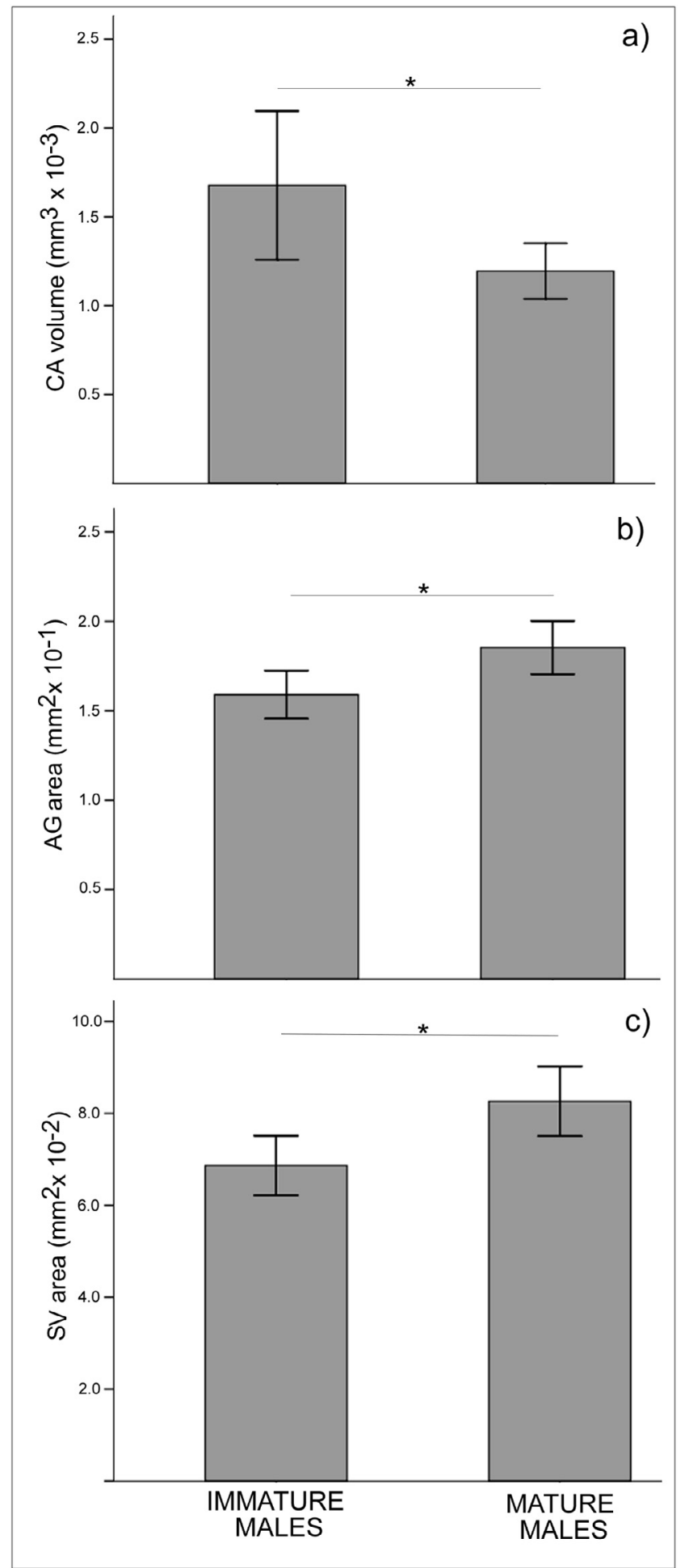

Fig. 1. Morphometric comparison between sexually immature and mature $P$. dominula males: bars represent the mean size of corpora allata CA (a), accessory glands AG (b) and seminal vesicles SV (c), while error bars represent the $95 \%$ confidence interval for the mean.

\subsection{Morphometric analyses}

We measured the apparatus of 59 males in total: 19 immature (12 unparasitized, 4 parasitized by one $X$. vesparum male, 3 by one female) and 40 mature ( 21 unparasitized, 14 parasitized by one male, 5 by one female). All specimens were killed by freezing $\left(-20^{\circ} \mathrm{C}\right)$. The abdomens were dissected in PBS to isolate the reproductive apparatus. Digital photographs of sexual organs (magnification 20x) were taken for each male. By using ImageJ software (http://rsbweb.nih.gov/ij/), we measured the mean area (in $\mathrm{mm}^{2}$ ) of left and right accessory glands (AG) and the mean area of the white inner portion of left and right seminal vesicles (SV), i.e. the portion containing sperms.

In a subset of 34 males, 11 immature ( 9 unparasitized, 2 parasitized) and 23 mature, (13 unparasitized, 10 parasitized) we measured head width, a reliable cue of body size (Eickworth, 1969), under a stereomicroscope Nikon $645 \mathrm{c}$-dss at $20 \times$ magnification. The head was dissected in phosphate buffered saline $\mathrm{pH}$ 6,8 (PBS) in order to isolate corpora allata CA $(50 \times$ magnification). The approximate CA volume $\left(\mathrm{mm}^{3}\right)$ was determined by measuring their relative area in $0.1 \mathrm{~mm}$ Burker chamber (Dapporto et al., 2010).

All statistical analyses were performed using SPSS (13.00). We first used Pearson correlation to test whether the size of CA, AG or SV was associated with head width in the subset of 34 males. Then, using the total sample of 59 males, we treated the measures of CA, SV and AG as dependent variables in three different ANCOVA GLM analyses to test for possible effects of age or parasitization on these measures (factorial predictors: parasite occurrence and age).

\subsection{Light and transmission electron microscopy}

Morphological observations were carried out on 14 immature males ( 9 unparasitized, 2 parasitized by one $X$. vesparum male, 3 by one female) and on 17 mature males ( 7 unparasitized, 4 parasitized by one male, 6 by one female). Males were dissected under an Olympus SZX12 stereo light microscope in a $0.1 \mathrm{M}$ sodium phosphate buffer, $\mathrm{pH} 7.2$, to which $3 \%$ sucrose was added (PB). Gonads were isolated and fixed in $2.5 \%$ glutaraldehyde buffered in PB overnight at $4{ }^{\circ} \mathrm{C}$. Samples were carefully rinsed in $\mathrm{PB}$, post-fixed with $1 \%$ osmium tetroxide, and then rinsed again in PB. After dehydration through graded series of ethanol, the material was embedded in Epon-Araldite resin. Semi-thin sections $(1 \mu \mathrm{m})$ were cut with a Reichert Ultracut $\mathrm{E}$ ultramicrotome, mounted on glass slides, lightly stained with $1 \%$ toluidine blue, and observed under a Leica DMRB interference contrast microscope. Images were taken with an Axiocam digital photocamera (Carl Zeiss). Ultrathin sections $(60 \mathrm{~nm})$ were routinely stained with uranyl acetate and lead citrate, and observed with a CM10 Philips transmission electron microscope (TEM) operating at an accelerating voltage of $80 \mathrm{kV}$.

\subsection{Electrophoresis and protein assay analysis of the male accessory glands}

The reproductive apparatus of 12 unparasitized and 12 parasitized mature males, infected by $7 X$. vesparum males and by 5 females, were previously stored at $-20^{\circ} \mathrm{C}$ and dissected as reported above in PBS at $\mathrm{pH}$ 6.8. Accessory glands (AG) of the two groups of males were removed, separately pooled in batches of 4-8 males equivalent (8-16 glands, $5 \mu \mathrm{PBS} /$ gland) and stored at $-20^{\circ} \mathrm{C}$. After thawing, the material was processed to recover hydrophilic secretion proteins as previously described (Marchini et al., 2003) with minor modifications. Homogenization was carried out in $1.5 \mathrm{~mL}$ Eppendorf tubes with Eppendorf micropestles for $5 \mathrm{~min}$ on ice. After centrifuging at $16,000 \mathrm{~g}$ for $30 \mathrm{~min}$ at $4{ }^{\circ} \mathrm{C}$, the supernatant was collected. After withdrawing proper volumes to perform the protein assay according to Bradford (1976) and using BSA as standard, samples were lyophilized. SDS-polyacrylamide gel electrophoresis (PAGE), 15 or $20 \%$ gel, was carried out according to Laemmli (1970). Before running the gel, samples were re-suspended in distilled water, denatured in dissociation buffer (Laemmli, 1970) and boiled for $5 \mathrm{~min}$ and spun at 16,000 $\mathrm{g}$ for $2 \mathrm{~min}$ at room temperature to remove any debris. High and low molecular weight standards, ranging from 2.5 to $31 \mathrm{kDa}$ and from 14 to $180 \mathrm{kDa}$, were purchased from Promega and Molecular Probes-Invitrogen, respectively. Proteins were revealed by Sypro Ruby protein gel stain (Molecular Probes-Invitrogen). Images were taken with a BIO-RAD Molecular Imager gel doc XR System. 


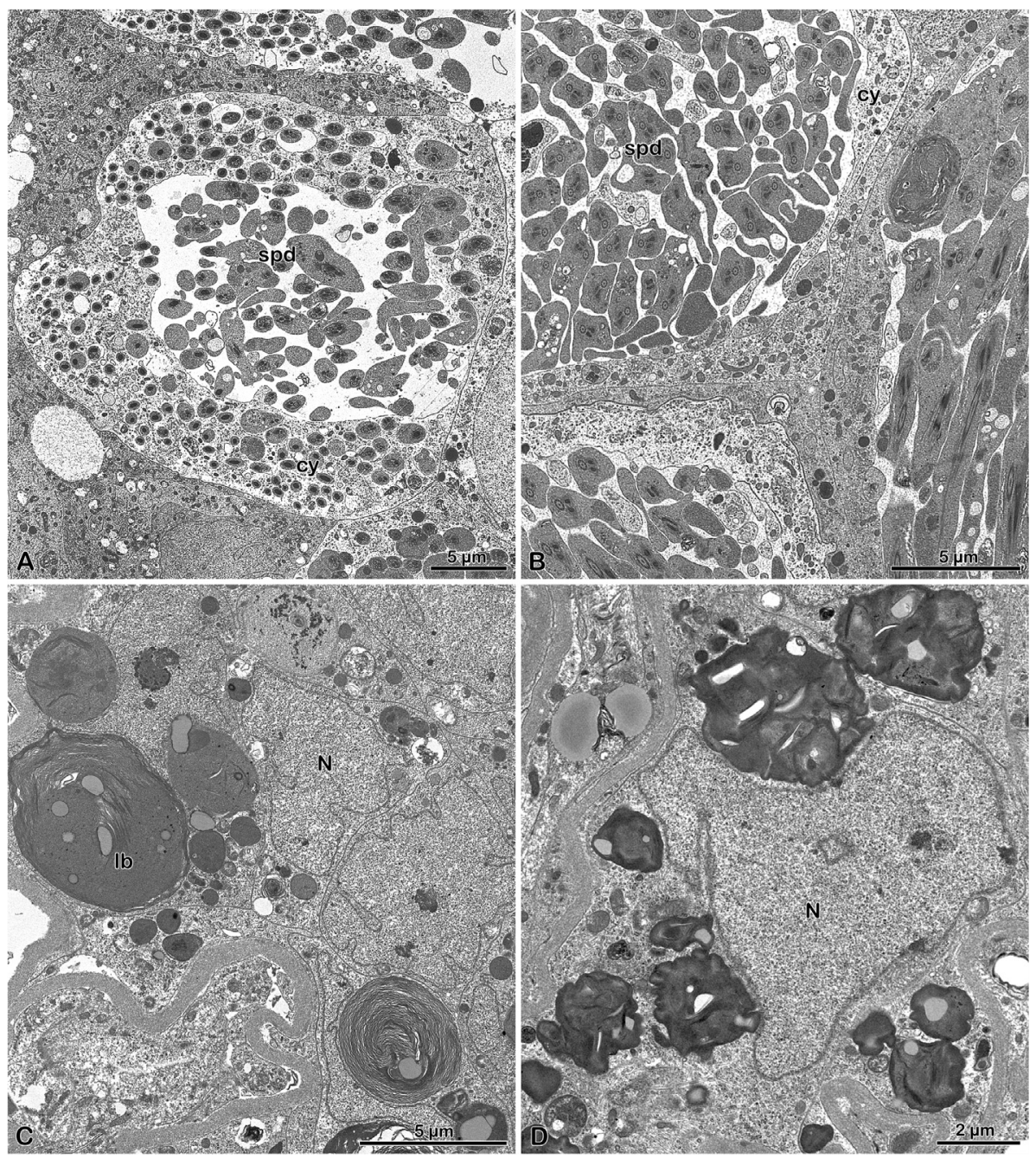

Fig. 2. Cross sections of testes in immature (A-B) and mature (C-D) $P$. dominula males. A. unparasitized: early stages of spermatids (spd) that penetrate into the germ cysts (cy). B. parasitized: germ cysts (cy) filled with spermatids (spd). C. unparasitized: in the cytoplasm undifferentiated germ cells and many large electrondense lamellated bodies (lb) D. parasitized: large dense bodies. N, nucleus.

\section{Results}

\subsection{Morphometric analysis of the reproductive and neuro-endocrine apparatus}

CA volume (Pearson corr. $=0.234 ; \mathrm{p}=0.183 ; \mathrm{N}=34$ ), as well as AG (Pearson corr. $=0.102 ; \mathrm{p}=0.568 ; \mathrm{N}=34$ ) and SV area (Pearson corr. $=0.249 ; \mathrm{p}=0.156 ; \mathrm{N}=34$ ), were not associated with head width, confirming previous findings on male reproductive apparatus and body size (see Beani and Zaccaroni, 2015). CA volume (Table 1) was significantly affected by age $(\mathrm{F}=7.386, \mathrm{P}=0.011, \mathrm{~N}=34$; Fig. 1a) but not by one parasite $(\mathrm{F}=0.003, \mathrm{P}=0.956, \mathrm{~N}=34)$. AG area (Table 1 ) was significantly affected by sexual maturity ( $F=5.004$, $\mathrm{P}=0.029, \mathrm{~N}=59$; Fig. $1 \mathrm{~b})$ and not by the parasite $(\mathrm{F}=0.002$, $\mathrm{P}=0.966, \mathrm{~N}=59$ ). Similarly, $\mathrm{SV}$ area (Table 1 ) was affected by sexual maturity $(\mathrm{F}=5.491, \mathrm{P}=0.023, \mathrm{~N}=59$; Fig. $1 \mathrm{c})$, and not by the parasite $(\mathrm{F}=0.005, \mathrm{P}=0.946, \mathrm{~N}=59)$.

\subsection{TEM observations}

\subsubsection{Testes}

The testes of unparasitized immature males are filled with several germ cysts rich in spermatids at different stages of maturation. Well differentiated spermatids deeply penetrate into the cytoplasm of the cyst cell, containing differently sized vesicles and electron-transparent bodies (Fig. 2A). Degeneration of germ cysts is revealed by large electron-dense bodies in unparasitized mature males (Fig. 2C). No notable differences were observed in testes of parasitized males (Fig. 2B and D), regardless of host age.

\subsubsection{Seminal vesicles}

There was no evidence of any effect of one parasite on SV structure in comparison to unparasitized ones. In immature males, SV are provided with high epithelial cells joined by apical zonula adherens and long septate junctions. Starting from the apical region, there are long microvilli, a layer of cytoplasm without organelles (Fig. 3A), and a thick region rich in mitochondria intermingled with small spherical bodies (Fig. 3A). In the basal epithelial region, scattered Golgi complexes, endoplasmic reticulum cisterns, many electron-dense vesicles $(0.5-1 \mu \mathrm{m}$ in diameter) and roundish nuclei $(10-15 \mu \mathrm{m}$ in diameter) are visible (Fig. 3A). In parasitized mature males several sperm bundles in the lumen are surrounded by large amount of masses of secretion (Fig. 3B). The rich system of mitochondria is located beneath the microvilli whereas the apical layer of dense cytoplasm is lacking, in comparison to immatures (Fig. 3C). The microvilli appear bent due to the presence of many sperm embedded in a very finely granular material (Fig. 3C).

\subsubsection{Accessory glands}

The AG epithelium is about $35 \mu \mathrm{m}$ high in unparasitized immature males, with basal elliptic nucleus, $15 \mu \mathrm{m}$ long and $5 \mu \mathrm{m}$ large (Fig. 4A). Long microvilli are present in the apical region while in the cytoplasm a few mitochondria, Golgi apparatuses, short endoplasmic reticulum cisterns and electron-dense vesicles are present. Beneath the epithelium 


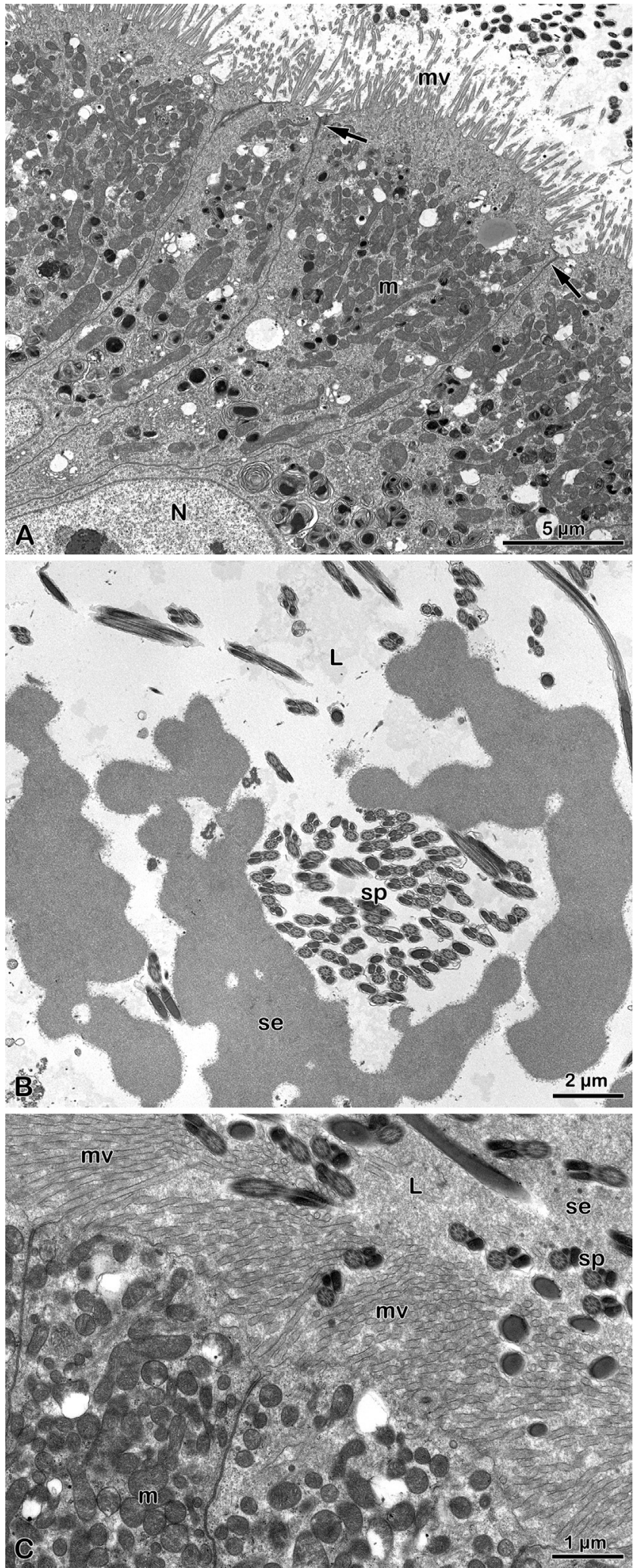

Fig. 3. Cross sections of seminal vesicles in parasitized males. A. Immature stage: elongated microvillated epithelial cells, apically joined by zonulae adherentes (arrows) and septate junctions. Beneath the microvilli (mv), a layer of cytoplasm devoid of organelles; under this layer, large number of mitochondria (m), intermingled with spherical dense bodies. N, nucleus. B. Mature stage: in the lumen (L) bundles of sperm (sp) and dense masses of secretion (se). C. Mature stage: epithelial microvillated epithelial cells, devoid of cytoplasm layer, with mitochondria (m) close to the microvilli (mv). In the lumen (L), the large amount of sperm cells (sp) inside a dense secretion (se) bend the microvilli. several striated muscles fibres are visible (Fig. 4A). In the lumen of mature unparasitized males, electron-dense vesicles of about $0.1-0.5 \mu \mathrm{m}$ in diameter are embedded in a loosely system of finely fibrous material (Fig. 4B). The microvillated epithelium becomes thinner (12 $\mu \mathrm{m}$ high) and epithelial cells are joined by very convoluted intercellular junctions in mature males (Fig. 4C). Clusters of dense vesicles are visible in the cytoplasm, while in the lumen dense vesicles increase in number and in size, reaching $1.2 \mu \mathrm{m}$ in diameter (Fig. 4C).

In parasitized males the lumen becomes rich in electron-dense material and the previously described loosely material now appears more dense and fibrous, both in immature (Fig. 5A and inset) and mature subjects (Fig. 5B and inset)

\subsubsection{Protein analyses of the accessory gland secretion}

AG secretion from parasitized and unparasitized males showed different total protein content, about 0.16 and $0.47 \mu \mathrm{g}$ protein/male, respectively. SDS-PAGE revealed a very similar band pattern in the two male groups. Protein species were found ranging from 90 to $3 \mathrm{kDa}$, with major bands distributed throughout the entire molecular mass range. However, the intensity of the bands appeared quite different in parasitized or unparasitized males in two different batches. The protein profile from unparasitized males was more intensely marked in 90-26 kDa molecular mass range with respect to parasitized males (Fig. 6) and this difference was constant in different batches (not shown). On the contrary, the low molecular mass bands (10-18 kDa) were more prominent in parasitized than in unparasitized males (Fig. 6).

\section{Discussion}

\subsection{The subtle effect of the parasite on the male neuroendocrine system}

endo-parasitic insects, developing in the body cavity of other insect hosts, are exposed to a gender-dependent hormonal milieau. In the Polistes-Xenos system, the parasitic effect on host's endocrine equilibrium that completely inhibits ovary development in females, does not seem to disrupt the deeper structure and physiology of the male apparatus. This is in agreement with our preliminary analysis at light microscope that showed no significant effect of one parasite either male or female on the general appearance of male's reproductive organs (Cappa et al., 2014). In the present study, the combined experimental approaches - morphometry, ultrastructure and analysis of protein secretion of accessory glands - enabled us to prove for the first time that $X$. vesparum does not induce sterility in the male host, unlike the drastic castration observed in female hosts even after parasitization by a single $X$. vesparum (Beani et al., 2011). In this previous study, parasitized females were collected in the field from the same population of males, whereas age effects were not evaluated in this field sample because ovaries are undeveloped at wasp emergence until the following season.

Our results show that the volume of Corpora Allata (CA), the source of juvenile hormone ( $\mathrm{JH})$, is not affected by a low parasite load,. Instead, it is significantly influenced by age, as these organs are larger in immature than in mature males. JH plays a plethora of physiological functions in insects, regulating development, the immune system and behaviour (Williams, 1956; Nijhout and Wheeler, 1982; Rantala et al., 2003; Amdam et al., 2004, 2005; Gilbert, 2012; Jindra et al., 2013). Most importantly, JH exerts a gonadotrophic function in many social Hymenoptera, including $P$. dominula females. In fact, high levels of this hormone in wasp foundresses are associated with high fertility and dominant behaviour (Tibbetts and Izzo, 2009). Interestingly, parasitism by $X$. vesparum disrupts $\mathrm{JH}$-secreting $\mathrm{CA}$ in female wasps and consequently castrates the female host (Röseler et al., 1980), regardless of parasite load and sex (Beani et al., 2011). Female wasps are irreversibly castrated due to the early CA inhibition, since parasite removal from adult females does not restore the host normal reproductive physiology (Strambi and Girardie, 1973; Strambi et al., 1982). Conversely, X. 


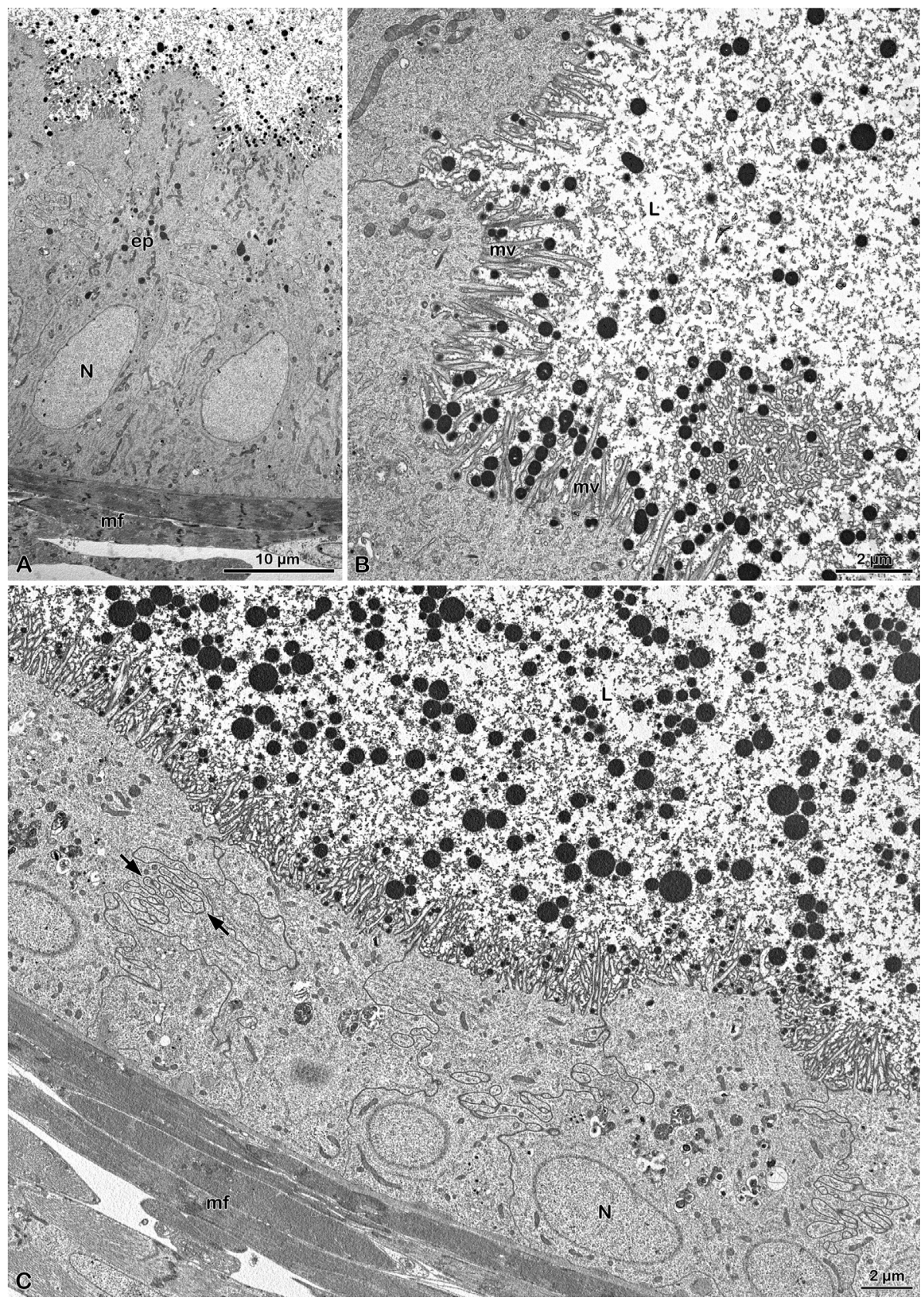

Fig. 4. Cross sections of accessory glands in unparasitized males. A. Immature stage: high microvillated epithelial layer (ep), nuclei $(\mathrm{N})$ in the basal region, muscle fibres (mf) beneath the epithelium. B. Mature stage: apical region of epithelial cells with regularly arranged microvilli (mv) intermingled with dense globular bodies. In the lumen (L), scattered dense globules in a loosely fibrous material. C. Mature stage: thin microvillated epithelium with cells joined by convoluted lateral plasma membranes (arrows) and in the lumen (L) a large number of electron-dense globular bodies. N, nucleus; mf, muscle fibres.

vesparum does not impact the $\mathrm{JH}$ pathway in male hosts and this could be one mechanism by which male hosts maintain their sexual maturation and activity. However, it is not clear what role $\mathrm{JH}$ plays during sexual maturation in males. In contrast with the large knowledge on how $\mathrm{JH}$ participate in oogenesis in female insects, its role in the maturation of male reproductive organs has been investigated only partially so far. In many insects JH does not appear to regulate spermiogenesis in the testes (Wyatt and Davy, 1996); on the other hand, JH may promote the secretory activity of accessory glands (Harano, 2013). These observations indicate that neuroendocrine mechanisms differ between males and females, highlighting the need to extend the analysis of the effect of one or more parasites also to the neglected male social Hymenoptera (Beani et al., 2014).

The morphological analyses of $P$. dominula testes show that age, and not parasitization, has an effect on male spermatogenesis, at least in the case of one parasite. Age is a factor affecting male sexual maturation in this insect (Salerno and Turillazzi, 2001; Cappa and Beani, unpublished data): maturation of sperm cells proceeds after male emergence and testes progressively degenerate with age (Salerno and Turillazzi, 2001; Cappa et al., 2014). While immature testes are filled with sperm cysts rich in spermatids, mature testes display sperm cysts that appear depleted: this is an evident sign of a reduction in the organ functioning and tissue degradation a few days after eclosion, in wasps as ell as in other social hymenopterans (Moors et al., 2009). Conversely, we do not observe any relevant difference in the structure of testes of parasitized males compared to unparasitized, indicating that there is no effect of a single parasite at this level. Similarly, also the physiology of seminal vesicles is affected by male age but not by the parasite: SV of mature males are filled with sperm and display larger size compared to immatures. The epithelium of these vesicles shows a number of dense secretions intermingled with numerous mitochondria under a thin apical layer of cytoplasm beneath the microvilli. In mature subjects, the increased amount of secretion present in the lumen could be responsible for the bending of microvilli and the lack of the cytoplasm layer that were observed at the electron microscope. In line with the other observations, also the accessory glands (AG) do not change in size 

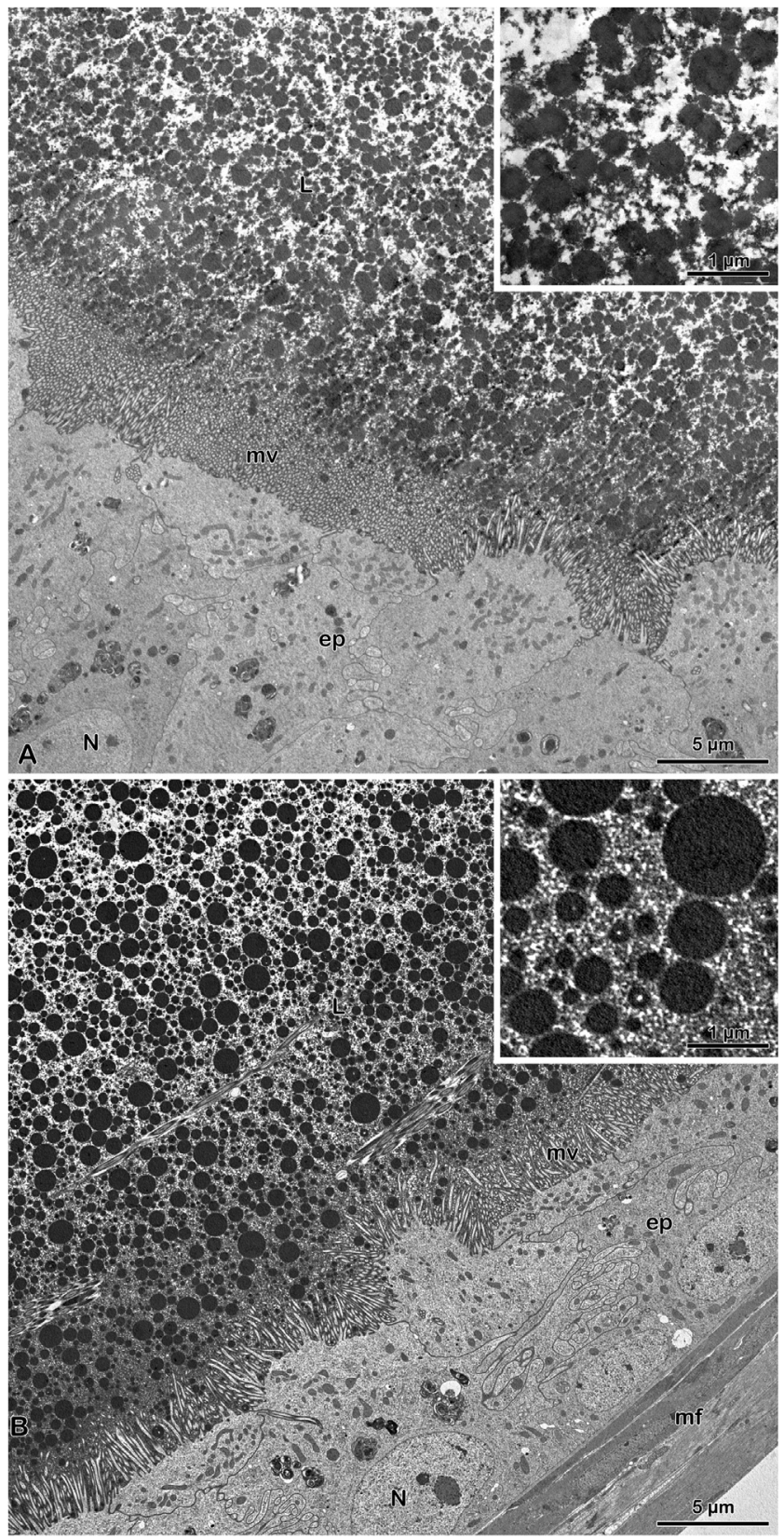

Fig. 5. Cross sections of accessory glands in parasitized males. A. Immature stage: thick microvillated (mv) epithelium (ep) surrounding a large lumen (L) filled with electron dense globules. Inset: detail of the lumen with dense globules immersed in a fibrous material. N, nucleus. B. Mature stage: thin microvillated (mv) epithelium (ep), lumen (L) filled with globules in a very dense fibrous material, muscle fibres (mf) beneath the epithelium. N, nucleus. Inset: detail of the electron dense fibrous material and globules.

after parasitization, but are affected by age. The gland epithelium of mature males is thinner compared to immatures, due to the increased secretory activity after male emergence, as described in Vespula vulgaris (Moors et al., 2009). The only noticeable effect of the parasite on the functional morphology of male reproductive apparatus is indeed the abundant fibrous material embedding electron-dense globules inside the AG lumen.

Intriguingly, the analysis of the protein content of AG supports the difference between parasitized and unparasitized males that was also observed at the morphological level. AG secretion from parasitized males contains about one third of the total protein content compared to unparasitized males. The electrophoretic analysis mirrors this difference, showing that qualitatively similar protein patterns are quantitatively different: proteins of high-medium molecular weight range are

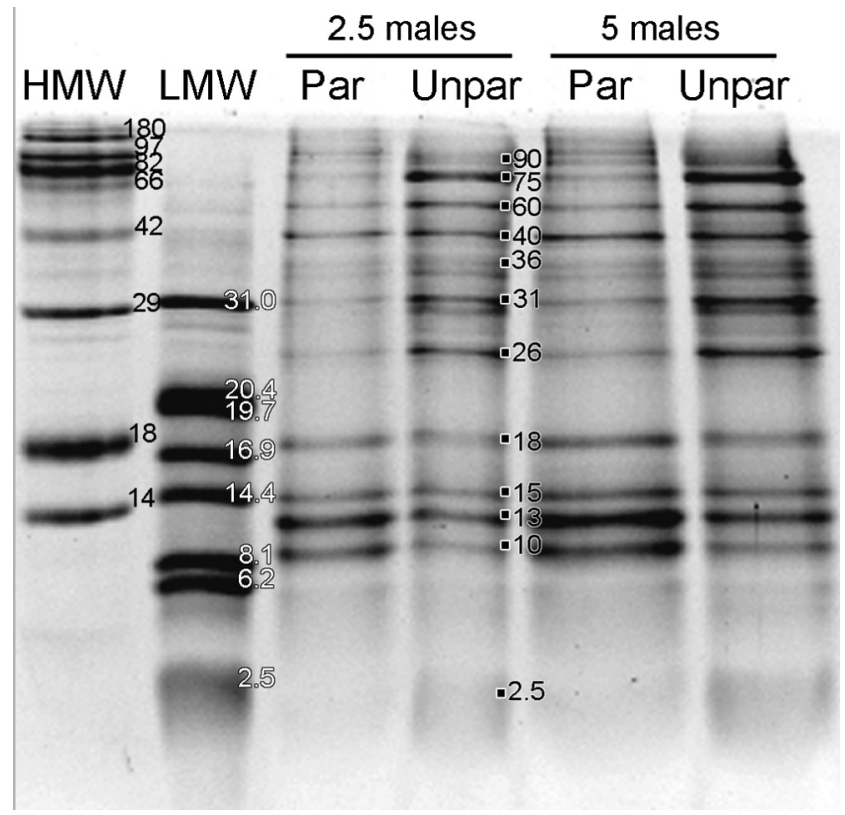

Fig. 6. SDS-PAGE (20\% gel) of accessory gland secretion from parasitized (Par) and unparasitized (Unpar) Polistes dominula males (2.5 or 5 male equivalent/lane, respectively, as indicated at the top of the panel). HMW and LMW, molecular mass markers, $1 \mu \mathrm{g}$ protein/band. The molecular mass of the main proteins is indicated, in $\mathrm{kDa}$, beside to the bands.

less intensely stained in parasitized males (denoting lower abundance of these proteins), whereas we observe the reverse for low molecular mass bands. Thus, it seems that Xenos parasites do not only affect the total protein content, but also the composition of the AG secretion: the same proteins have different ratios in the two groups. We can only speculate that the abundant low molecular weight proteins might be related to a peculiar enzymatic activity induced by one parasite developing with its host (i.e. hydrolysis of high molecular mass proteins), in turn resulting in a differently condensed material in the gland lumen as observed at TEM. Alternatively, the fibrous electron-dense material in the gland lumen could be associated with a non-protein substance of unknown nature. If this difference in secretion, as well as in its quantity, implies any functional effect on the ejaculate it is still unknown. We only ascertained that sperm cells are motile (thus viable) in both male groups (pers. obs.). As observed in other insects (Happ, 1992; Gillot, 1996; Gillott, 2003), also in Polistes the long storage of male sperm in the female spermatheca before egg fertilization could support a role for AG secretion as a key player involved in both male and female reproduction. In a previous experiment, $P$. dominula males with larger glands mated at a higher frequency than did males with smaller glands, regardless of their body size (Beani and Zaccaroni, 2015), and a similar relationship was recorded in Drosophila melanogaster (Bangham et al., 2002). The development of male reproductive organs, unrelated to body size, mirrors the weak link between ovaries and body size in $P$. dominula females (Dapporto and Palagi, 2006).

\subsection{Life-history trajectories are gender-related in parasitized wasps: Xenos as parasitoid in female hosts but true parasite in males}

The subtle effect of $X$. vesparum on the male reproductive apparatus - only at the level of AG secretion - is compelling if we compare it to the broad impact of the parasite on the reproductive physiology of female host (see the previous section). Dramatic alterations are also induced by the parasite on the behaviour of female wasps: if infected, they are turned into gregarious 'zombies' regardless of their putative rank, i.e. workers or gynes (Beani, 2006; Beani et al., 2011; Cappa et al., 2014; Geffre et al., 2017). They leave their colonies few days after emergence without performing any social task, select peculiar sites where they 
search for shelter and nutrients to survive outside the nest, cluster to favour the parasite mating (Hughes et al., 2004; Beani et al., 2005) and overwinter in aggregations with future queens (Beani et al., 2011). Conversely, males parasitized by one Xenos male or female maintain their sexual behaviour during lab trials (Cappa et al., 2013, 2014) and in the field, where they typically gather at leks and defend their territory.

Examples of different host-parasite dynamics that depend on host's gender are widespread and well described in the literature. For example, differences in parasite prevalence between males and females are found in a wide range of taxa (see Zuk and McKean, 1996). Intriguingly, males usually show greater parasite prevalence (Klein, 2000; Zuk and Stoehr, 2002; Zuk, 2009; Schmid-Hempel, 2011), due to a trade-off between mating efforts and immunocompetence - and consequently susceptibility to disease: the more resources are spent to procure a mate the less are available for defense against parasites (Schmid-Hempel, 2005). Females, instead, generally do not show this trade-off as they gain reproductive fitness by living longer (i.e. producing multiple offsprings), hence they evolved adaptations to maintain their immune competence at higher levels (Rolff, 2002). In social Hymenoptera it has also been proposed that males should be more sensitive to diseases because of their haploid condition that reduces the availability of genetic combinations capable to provide resistance against parasites (O'Donnell and Beshers, 2004). However, recent results produced by our research group do not provide support for a fundamental role of ploidy in the determination of male immunocompetence: $P$. dominula males, who survive for weeks far from the protection of their nest, show a higher immune competence in terms of bacterial clearance with respect to female workers of the same age (Cappa et al., 2015). The different effect of host gender in the PolistesXenos system could be explained with a more parsimonious approach, i.e. in terms of parasite adaptations to the host gender more commonly encountered (Duneau and Ebert, 2012; Duneau et al., 2012). Polistes colonies are essentially female worlds, thus the intimate relationship between $X$. vesparum and $P$. dominula occurs mainly in the 'female environment' of the host. In this perspective, Polistes males represent a secondary host for Xenos (Hughes et al., 2004). They might act as a vector for the parasite when they fly at leks to mate (Beani et al., 2005; Cappa et al., 2014), enabling the parasite to easily find a mate nearby. However they are a dead end for the Xenos female, as they die in the autumn and by doing so they interrupt the life cycle of the female parasite: winter aggregations do not include males (Beani et al., 2011). Strepsiptera, previously considered parasitoids (Kathirithamby, 2009), "sit very close to the parasite-parasitoid boundary" (McMahon et al., 2011), and this is now supported by our results. It will be of great interest in the future to investigate how the viability of male hosts might be influenced by the sex of this parasitic insect at its last developmental stage (after male extrusion from cephalotheca wasps can survive for a relatively long period), and by a larger number of $X$. vesparum within the same wasp. To date, our results show that $X$. vesparum appears to behave as a true parasite in male $P$. dominula wasps, in clear opposition to the role of parasitoid or castrator that it plays in female hosts.

\section{Acknowledgements}

We are thankful to David Mercati (University of Siena) for his help in the preparation of figures.

\section{References}

Alcock, J., Thornhill, R., 2014. The evolution of insect mating systems. In: York, New. (Ed.), The Evolution of Insect Mating Systems, Shuker and Simmons. Oxford University Press, NY, pp. 275-278.

Amdam, G.V., Simões, Z.L., Hagen, A., Norberg, K., Schrøder, K., Mikkelsen, Ø., Kirkwood, T.B., Omholt, S.W., 2004. Hormonal control of the yolk precursor vitellogenin regulates immune function and longevity in honeybees. Exp. Gerontol. 39 (5), 767-773
Amdam, G.V., Aase, A.L.T., Seehuus, S.C., Fondrk, M.K., Norberg, K., Hartfelder, K., 2005 Social reversal of immunosenescence in honey bee workers. Exp. Gerontol. 40 (12), 939-947.

Araùjo, V.A., Moreira, J., Lino-Neto, J., 2010. Morphology of the male reproductive system of the social wasp, Polistes versicolor versicolor, with phylogenetic implications. J. Insect Sci. 10, 1-10.

Baer, B., 2014. Sexual selection in social insects. In: York, New. (Ed.), The Evolution of Insect Mating Systems, Shuker and Simmons. Oxford University Press, NY, pp. 261-274.

Baer, B., Schmid, Hempel P., 2006. Phenotypic variation in male and worker encapsulation response in the bumblebee. Ecol. Entomol. 31, 591-596.

Bangham, J., Chapman, T., Partridge, L., 2002. Effects of body size, accessory gland and testis size on pre- and postcopulatory success in Drosophila melanogaster. Anim. Behav. 64 (6), 915-921.

Baudoin, M., 1975. Host castration as a parasitic strategy. Evolution 29, 335-352.

Beani, L., 1996. Lek-like courtship in paper wasps: "a prolonged, delicate, and troublesome affair". In: Turillazzi, West-Eberhard (Eds.), The Natural History and Evolution of Paper-wasps. Oxford University Press, pp. 113-125.

Beani, L., 2006. Crazy wasps: when parasites manipulate the Polistes phenotype. Ann. Zool. Fenn. 43, 564-574.

Beani, L., Zaccaroni, M., 2015. Experimental male size manipulation in Polistes dominula paper wasps: to be of the right size. Ethol. Ecol. Evol. 27, 185-189.

Beani, L., Giusti, F., Mercati, D., Lupetti, P., Paccagnini, E., Turillazzi, S., Dallai, R., 2005. Mating of Xenos vesparum (Rossi) (Strepsiptera, Insecta) revisited. J. Morphol. 265, 291-303.

Beani, L., Dallai, R., Mercati, D., Cappa, F., Giusti, F., Manfredini, F., 2011. When a parasite breaks all the rules of a colony: morphology and fate of wasps infected by a strepsipteran endoparasite. Anim. Behav. 82, 1305-1312.

Beani, L., Dessì-Fulgheri, F., Cappa, F., Toth, A., 2014. The trap of sex in social insects: from the female to the male perspective. Neurosci. Biobehav. Rev. 46, 519-533.

Berens, A.J., Hunt, J.H., Toth, A.L., 2015. Nourishment level affects caste-related gene expression in Polistes wasps. BMC Genomics 16, 235.

Berens, A.J., Tibbetts, E.A., Toth, A.L., 2016. Candidate genes for individual recognition in Polistes fuscatus paper wasps. J. Comp. Physiol. A. 202, 115-129.

Boomsma, J.J., Baer, B., Heinze, J., 2005. The evolution of male traits in social insects. Annu. Rev. Entomol. 50, 395-420.

Boomsma, J.J., Kronauer, D.J.C., Pedersen, J.S., 2009. The evolution of social insect mating systems. In: Gadau, Fewell (Eds.), Organization of Insect Societies: From Genome to Sociocomplexity. Harvard University Press, Cambridge, MA, pp. 3.

Bradford, M.M., 1976. A rapid and sensitive method for the quantitation of microgram quantities of protein utilizing the principle of protein-dye binding. Anal. Biochem. $72,248-254$.

Cappa, F., Bruschini, C., Cervo, R., Turillazzi, S., Beani, L., 2013. Males do not like the working class: male sexual preference and recognition of functional castes in a primitively eusocial wasp. Anim. Behav. 86, 801-810.

Cappa, F., Manfredini, F., Dallai, R., Gottardo, M., Beani, L., 2014. Parasitic castration by Xenos vesparum depends on host gender. Parasitology 141, 1080-1087.

Cappa, F., Beani, L., Cervo, R., Grozinger, C., Manfredini, F., 2015. Testing male immunocompetence in two hymenopterans with different levels of social organization: 'live hard, die young?'. Biol. J. Linn. Soc. 114, 274-278.

Cappa, F., Beani, L., Cervo, R., 2016. The importance of being yellow: visual over chemical cues in gender recognition in a social wasp. Behav. Ecol. 27, 1182-1189.

Carpenter, J.M., 2003. On "Molecular phylogeny of vespidae (hymenoptera) and the evolution of sociality in wasps". Am. Mus. Natl. Hist. 3389, 1-20.

Cook, J.L., 2014. Review of the biology of parasitic insects in the order Strepsiptera. Comp. Parasitol. 81, 134-151.

Dapporto, L., Palagi, E., 2006. Wasps in the shadow: looking at the pre-hibernating clusters of Polistes dominulus. Ann. Zool. Fenn. 43, 583-594.

Dapporto, L., Bruschini, C., Cervo, R., Petrocelli, I., Turillazzi, S., 2010. Hydrocarbon rank signatures correlate with differential oophagy and dominance behaviour in Polistes dominulus foundresses. J. Exper. Biol. 213, 453-458.

de Souza, A.R., Júnior, A.M.C., Nascimento, F.S., Lino-Neto, J., 2014. Sexy faces in a male paper wasp. PLoS One 9, e98172.

Dirks, T.F., Sternburg, J.G., 1972. Male reproductive system of three species of Polistes (hymenoptera: vespidae). J. Insect Morphol. Embryol. 1, 315-320.

Duneau, D., Ebert, D., 2012. Host sexual dimorphism and parasite adaptation. PLoS Biol. 10, e1001271.

Duneau, D., Luijckx, P., Ruder, L.F., Ebert, D., 2012. Sex-specific effects of a parasite evolving in a female-biased host population. BMC Biol. 10, 104.

Ebert, D., Carius, H.J., Little, T., Decaestecker, E., 2004. The evolution of virulence when parasites cause host castration and gigantism. Am. Nat. 164, S19-S32.

Eickworth, K., 1969. Separation of the castes of Polistes exclamans and notes on its biology (Hym:Vespidae). Insectes Soc. 16, 67-72

Geffre, A.C., Liu, R., Manfredini, F., Beani, L., Kathirithamby, J., Grozinger, C.M., Toth, A., 2017. Transcriptomics of an extended phenotype: parasite manipulation of wasp social behaviour shifts expression of caste-related genes. Proc. R. Soc. B 284, 20170029.

Gilbert, L.I. (Ed.), 2012. The Juvenile Hormones. Springer Science \& Business Media.

Gillot, C., 1996. Male insect accessory glands: functions and control of secretory activity. Invertebr. Reprod. Dev. 30, 199-205.

Gillott, C., 2003. Male accessory gland secretions: modulators of female reproductive physiology and behavior. Annu. Rev. Entomol. 48, 163-184.

Happ, G.M., 1992. Maturation of the male reproductive system and its endocrine regulation. Annu. Rev. Entomol. 37, 303-320.

Harano, K.I., 2013. Effects of juvenile hormone analog on physiological and behavioral maturation of honeybee drones. Apidologie 4, 586-599. 
Hechinger, R.F., Lafferty, K.D., Mancini, F.T., Warner, R.R., Kuris, A.M., 2009. How large is the hand in the puppet? Ecological and evolutionary factors affecting body mass of 15 trematode parasitic castrators in their snail host. Evol. Ecol. 23, 651-667.

Heinze, J., 2016. The male has done his work — the male may go. Curr. Opin. Insect Sci. $16,22-27$.

Hiroki, M., Tagami, Y., Miura, K., Kato, Y., 2004. Multiple infection with Wolbachia inducing different reproductive manipulations in the butterfly Eurema hecabe. Proc. R. Soc. B Biol Sci. 271, 1751-1755.

Hughes, D.P., Beani, L., Turillazzi, S., Kathirithamby, J., 2003. Prevalence of the parasite Strepsiptera in Poliste sas detected by dissection in immatures. Insectes Soc. 50, $62-68$.

Hughes, D.P., Kathirithamby, J., Turillazzi, S., Beani, L., 2004. Social wasps desert the colony and aggregate outside if parasitized: parasite manipulation? Behav. Ecol. 15 (6), 1037-1043.

Izzo, A.S., Tibbetts, E.A., 2012. Spotting the top male: sexually selected signals in male Polistes dominulus wasps. Anim. Behav. 83, 839-845.

Jamieson, B.G.M., Dallai, R., Afzelius, B.A., 1999. Insects: Their Spermatozoa and Phylogeny. Science Publishers Inc.pp. 555.

Jandt, J.M., Thomson, J.L., Geffre, A.C., Toth, A., 2015. Lab rearing environment perturbs social traits: a case study with Polistes wasps. Behav. Ecol. 1-11. http://dx.doi.org/ 10.1093/beheco/arv082.

Jindra, M., Palli, S.R., Riddiford, L.M., 2013. The juvenile hormone signaling pathway in insect development. Annu. Rev. Entomol. 58, 181-204.

Kathirithamby, J., 2009. Host-parasitoid associations in Strepsiptera. Annu. Rev. Entomol. 54, 227-249.

Klein, S.L., 2000. The effects of hormones on sex differences in infection: from genes to behavior. Neurosci. Biobehav. Rev. 24 (6), 627-638.

Kuris, A.M., 1974. Trophic interactions-similarity of parasitic castrators to parasitoids. Q. Rev. Biol. 49, 129-148.

Laemmli, U.K., 1970. Cleavage of structural proteins during assembly of the head in bacteriophage T4. Nature 227, 680-685.

Lafferty, K.D., 1993a. Effects of parasitic castration on growth, reproduction and population dynamics of the marine snail Cerithidea californica. Mar. Ecol. Prog. Ser. 96, 229-237.

Lafferty, K.D., 1993b. The marine snail, Cerithidea californica, matures at smaller sizes where parasitism is high. Oikos 68, 3-11.

Lafferty, K.D., Kuris, A.M., 2009. Parasitic castration: the evolution and ecology of body snatchers. Trends Parasitol. 25, 564-572.

Lefèvre, T., Lebarbenchon, C., Gauthier-Clerc, M., Missé, D., Poulin, R., Thomas, F., 2009a. The ecological significance of manipulative parasites. Trends Ecol. Evol. 24, $41-48$.

Lefèvre, T., Adamo, S.A., Biron, D.G., Missé, D., Hughes, D., Thomas, F., 2009b. Invasion of the body snatchers: the diversity and evolution of manipulative strategies in hostparasite interactions. Adv. Parasitol. 68, 45-83.

Marchini, D., Del Bene, G., Cappelli, L., Dallai, R., 2003. Ultrastructure of the male reproductive accessory glands in the medfly Ceratitis capitata (Diptera: Tephritidae) and preliminary characterization of their secretions. Arthropod Struct. Dev. 31, 313-327.

McMahon, D.P., Hayward, A., Kathirithamby, J., 2011. Strepsiptera. Curr. Biol. 21, R271-R272.

Minchella, D.J., 1985. Host life history variation in response to parasitism. Parasitology 90, 205-216.

Moors, L., Schoeters, E., Coudron, K., Billen, J., 2009. Morphological changes in the male accessory glands and testes in Vespula vulgaris (Hymenoptera, Vespidae) during sexual maturation. Invertebr. Biol. 128 (4), 364-371.

Nijhout, H.F., Wheeler, D.E., 1982. Juvenile hormone and the physiological basis of insect polymorphisms. Q. Rev. Biol. 57, 109-133.

O'Donnell, S., Beshers, S., 2004. The role of male disease susceptibility in the evolution of haplodiploid insect societies. Proc. R. Soc. B Biol. Sci. 271, 979-983.

Pardi, L., 1948. Dominance order in polistes wasps. Physiol. Zool. 21, 1-13.

Poulin, R., 2011. Strategies of Host Exploitation. Evolutionary Ecology of Parasites. Princeton University Presspp. 96-132.

Rantala, M.J., Vainikka, A., Kortet, R., 2003. The role of juvenile hormone in immune function and pheromone production trade-offs: a test of the immunocompetence handicap principle. Proc. R. Soc. London B Biol. Sci. 270 (1530), 2257-2261.

Retschnig, G., Williams, G.R., Mehmann, M.M., Yanez, O., de Miranda, J.R., Neumann, P., 2014. Sex-specific differences in pathogen susceptibility in honey bees (Apis mellifera). PLoS One 9 (1), e85261.

Rolff, J., 2002. Bateman's principle and immunity. Proc. R. Soc. London B Biol. Sci. 269 (1493), 867-872.

Röseler, P.F., Röseler, I., Strambi, A., 1980. The activity of corpora allata in dominant and subordinated females of the wasp Polistes gallicus. Insectes Soc. 27, 97-107.

Ruiz-Gonzàlez, M.X., Brown, M.J.F., 2006. Honey bee and bumblebee trypanosomatids: specificity and potential for transmission. Ecol. Entomol. 31 (6), 612-622.

Salerno, G., Turillazzi, S., 2001. Morphology and post-emergence maturation of internal reproductive organs in Polistes dominulus males (Hymenoptera Vespidae). Bollettino Società Entomologica Italiana 133, 173-180.

Schmid-Hempel, P., 2005. Evolutionary ecology of insect immune defenses. Annu. Rev. Entomol. 50, 529-551.

Schmid-Hempel, P., 2011. Parasites, immunity and sexual selection. In: Schmid-Hempel (Ed.), Evolutionary Parasitology: The Integrated Study of Infections, Immunology, Ecology, and Genetics. Oxford University Press, Oxford, UK, pp. 141-163.

Schmitz, J., Moritz, R.F.A., 1998. Molecular phylogeny of Vespidae (Hymenoptera) and the evolution of sociality in wasps. Mol. Phylogenet. Evol. 9, 183-191.

Strambi, C., Girardie, A., 1973. Effet de l'implantation de corpora allata actifs de Locusta migratoria (Orthoptère) dans des femelles de Polistes gallicus L. (Hymenoptères Vespides) saines et parasitées par Xenos vesparum Rossi (Insecte Sterepsiptère). Compte Rendu de l'Academie des Sciences, Paris, D. 276, 3319-3322.

Strambi, C., Strambi, A., Augier, R., 1982. Protein level in the haemolymph of the wasp Polistes gallicus L. at the beginning of imaginal life and during overwintering. Action of the strepsipteran parasite Xenos vesparum Rossi. Experientia 38, 1189-1191.

Strassmann, J.E., 1981. Evolutionary implications of early male and satellite nest production in Polistes exclamans colony cycle. Behav. Ecol. Sociobiol. 8, 55-64.

Sumner, S., Pereboom, J.J.M., Jordan, W.C., 2006. Differential gene expression and phenotypic plasticity in behavioural castes of the primitively eusocial wasp, Polistes canadensis. Proc. R. Soc. B 273, 19-26.

Thornhill, R., Alcock, J., 1983. The Evolution of Insect Mating Systems. Harvard University Press, Cambridge., pp. 547.

Tibbetts, E.A., Izzo, M., 2009. Endocrine mediated phenotypic plasticity: condition dependent effects of juvenile hormone on dominance and fertility of wasp queens Horm. Behav. 56, 527-531.

Toth, A.L., Varala, K., Newman, T.C., Miguez, F.E., Hutchison, S.K., Willoughby, D.A. Simons, J.F., Egholm, M., Hunt, J.H., Hudson, M.E., Robinson, G.E., 2007. Wasp gene expression supports an evolutionary link between maternal behaviour and eusociality. Science 318, 441-444.

Toth, A.L., Varala, K., Henshaw, M.T., Rodriguez-Zas, S.L., Hudson, M.E., Robinson, G.E., 2010. Brain transcriptomic analysis in paper wasps identifies genes associated with behaviour across social insect lineages. Proc. R. Soc. B 277, 2139-2148.

Toth, A.L., Tooker, J.F., Radhakrishnan, S., Minard, R., Henshaw, M.T., Grozinger, C.M., 2014. Shared genes related to aggression, rather than chemical communication, are associated with reproductive dominance in paper wasps (Polistes metricus). BMC Genomics 15, 75 .

West-Eberhard, M.J., 1969. The social biology of polistine wasps. Miscellaneous Publications of the Museum of Zoology. vol. 140. University of Michiganpp. 1-101.

West-Eberhard, M.J., 2006. Polistine passions. In: Starks, P.T., Turillazzi, S. (Eds.), Polistes Wasps: The Emergence of a Model Genus. vol. 43. pp. 387-389 Annales Zoologici Fennici.

Williams, C.M., 1956. The juvenile hormone of insects. Nature 178, 212-213.

Wyatt, G.R., Davy, K.G., 1996. Cellular and molecular actions of Juvenile Hormone. II. Roles of Juvenile Hormone in adult insects. Adv. Insect Physiol. 26, 1-113.

Zuk, M., 2009. The sicker sex. PLoS Pathogen. 5 (1), e1000267.

Zuk, M., McKean, K.A., 1996. Sex differences in parasite infections: patterns and processes. Int. J. Parasitol.. 26, 1009-1024.

Zuk, M., Stoehr, A.M., 2002. Immune defense and host life history. Am. Nat. 160 (S4), S9-S22. 